\title{
Silver Decorated Reduced Graphene Oxide as Electrocatalyst for Zinc-Air Batteries
}

\author{
Laksanaporn Poolnapol ${ }^{1}$, Wathanyu Kao-ian ${ }^{1}$, Anongnat Somwangthanaroj ${ }^{1, *(1)}$, \\ Falko Mahlendorf ${ }^{2}$, Mai Thanh Nguyen ${ }^{3} \mathbb{D}$, Tetsu Yonezawa ${ }^{3,4} \mathbb{D}$ and \\ Soorathep Kheawhom 1,3,5,*1D \\ 1 Department of Chemical Engineering, Faculty of Engineering, Chulalongkorn University, Bangkok 10330, \\ Thailand; dearpenpal@hotmail.com (L.P.); wathanyu_pond@hotmail.com (W.K.-i.) \\ 2 Department of Energy Technology, University Duisburg-Essen, 47057 Duisburg, Germany; \\ falko.mahlendorf@uni-due.de \\ 3 Division of Materials Science and Engineering, Faculty of Engineering, Hokkaido University, \\ Hokkaido 060-8628, Japan; mai_nt@eng.hokudai.ac.jp (M.T.N.); tetsu@eng.hokudai.ac.jp (T.Y.) \\ 4 Institute of Business-Regional Collaborations, Hokkaido University, Hokkaido 001-0021, Japan \\ 5 Research Unit of Advanced Materials for Energy Storage, Chulalongkorn University, Bangkok 10330, \\ Thailand \\ * $\quad$ Correspondence: anongnat.s@chula.ac.th (A.S.); soorathep.k@chula.ac.th (S.K.)
}

Received: 3 December 2019; Accepted: 14 January 2020; Published: 17 January 2020

\begin{abstract}
Due to their low cost and very high energy density, zinc-air batteries (ZABs) exhibit high potential for various energy applications. The electrochemical performance of the air-cathode has a decisive impact on the discharge performance of ZABs because the sluggish oxygen reduction reaction (ORR) kinetics increase the overpotential of the air-cathode and hence the performance of ZABs. In this work, reduced graphene oxide decorated with silver nanoparticles (AgNP/rGO) is synthesized using simultaneous reduction of graphene oxide and silver ions. Different amounts of silver loading are examined for the synthesis of AgNP/rGO. The synthesized AgNP/rGO samples are analyzed using a rotating disk electrode in order to investigate ORR activity. Then, the synthesized $\mathrm{AgNP} / \mathrm{rGO}$ electrocatalyst is applied on a tubular designed zinc-air battery in order to study the performance of the zinc-air battery. Results demonstrate that $\mathrm{AgNP} / \mathrm{rGO}$ is an efficient and cost-effective ORR electrocatalyst for its practical application in ZABs.
\end{abstract}

Keywords: oxygen reduction; air cathode; zinc-air battery; silver; graphene; current density

\section{Introduction}

Electricity is the most important and convenient way of energy consumption. It is clean and efficient. It requires minimal maintenance and produces minimal pollution during consumption. An essential element for electrification is an electrical energy storage (EES) system [1]. The most common kind of EES system is a rechargeable battery [2]. Lithium-ion batteries (LIBs) provide the leading energy storage solution for various applications and are widely recognized as the most viable option [3]. Unfortunately, their limitations on high cost and safety issues are of prime concern [4-6].

Zinc-air batteries (ZABs) have exhibited high potential for various energy applications because of their cost effectiveness and very high energy density $(1.35 \mathrm{kWh} / \mathrm{kg})$ [7-10]. Zinc ( $\mathrm{Zn})$ is an attractive electrode material because it is light-weight, non-toxic, inherently safe, inexpensive, and abundant [11,12]. In addition, zinc is also the metal produced in the fourth largest quantity after iron $(\mathrm{Fe})$, copper $(\mathrm{Cu})$ and aluminum $(\mathrm{Al})$. Moreover, an established $\mathrm{Zn}$ recycling industry exists to reclaim $\mathrm{Zn}$ from its myriad uses in industry [13]. 
The mechanism behind ZABs involves $\mathrm{Zn}$ dissolution at the negative electrode (zinc anode) and oxygen reduction reaction (ORR) at the positive electrode (air cathode) [14,15]. The performance of the positive electrode has a decisive impact on the performance of ZABs because the sluggish ORR kinetics increase the overpotential and decrease the power density as well as the performance of ZABs [16]. The mechanism of ORR is complicated and involves many intermediates depending on the characteristics of the cathode, catalyst and electrolyte [17]. In aqueous solutions, the ORR can proceed by two pathways: a direct (four-electron) pathway and a peroxide (two-electron) pathway [18]. In the four-electron pathway, oxygen directly reduces to hydroxide ion $\left(\mathrm{OH}^{-}\right)$through dissociative adsorption of oxygen on the catalyst surface [19]. In comparison, in the two-electron pathway, an initial reduction to hydroperoxide ion $\left(\mathrm{HO}_{2}^{-}\right)$is followed by the reduction of $\mathrm{HO}_{2}{ }^{-}$to $\mathrm{OH}^{-}$.

For high performance ZABs, an efficient, durable and low-cost air-cathode with low polarization ORR is essential. In acidic and alkaline solution, platinum (Pt) is an excellent ORR electrocatalyst. Nonetheless, high cost and scarcity hinder its practical applications [20]. Silver (Ag) is a good alternative because it is significantly cheaper than platinum. The cost ratio of platinum to silver is currently about 60. In the earth's crust, silver is 15 times more abundant than platinum. Also, silver shows thermodynamically and electrochemically stable, with high ORR activity in alkaline media [21,22].

Graphene is a two-dimensional monolayer of carbon atoms densely packed in a honeycomb crystal lattice [23]. As a promising material for next-generation energy storage and conversion devices, graphene has attracted tremendous attention because of its superior properties [24-27]. Graphene exhibits a unique two-fold advantage with remarkably high electron mobility at room temperature and fast heterogeneous electron transfer at the edges. Besides, graphene has an ultra-high surface area of $2630 \mathrm{~m}^{2} \mathrm{~g}^{-1}$, which is significantly higher than its one-dimensional carbon nanotube $\left(1315 \mathrm{~m}^{2} \mathrm{~g}^{-1}\right)$ and three-dimensional graphite $\left(10 \mathrm{~m}^{2} \mathrm{~g}^{-1}\right)$ counterparts. Recently, graphene has obtained much attention as regards decoration with metal nanoparticles [28].

Tang et al. [29] demonstrated the synthesis of reduced graphene oxide (rGO) decorated with silver nanoparticles (AgNP) by simultaneous reduction of graphene oxide (GO) as well as silver ions. Kumar et al. [30] synthesized AgNP decorated on rGO and examined the ORR catalytic performance for rechargeable lithium- $\mathrm{O}_{2}$ batteries. Lim et al. [31] reported that AgNP was successfully anchored on rGO through simultaneous reduction of silver ions and GO without surfactants. Synthesized $\mathrm{AgNP} / \mathrm{rGO}$ improved ORR activity by changing the half-wave potential towards more positive values and increased ORR activity via a four-electron pathway in alkaline media. The results also indicated that $\mathrm{rGO}$ is an excellent support material providing a remarkably high specific surface area that can accommodate highly concentrated metal nanoparticles.

Soo et al. [32] demonstrated the preparation of silver particles on nitrogen-doped reduced graphene oxide $(\mathrm{Ag} / \mathrm{N}-\mathrm{rGO})$ by a simple thermal annealing of silver salts with $\mathrm{GO}$ and melamine. Results highlighted that $\mathrm{Ag} / \mathrm{N}-\mathrm{rGO}$ has the potential to substitute the platinum on the carbon $(\mathrm{Pt} / \mathrm{C})$ catalyst for ORR in alkaline media because of its lower cost and excellent ORR catalytic performance.

Wang et al. [33] focused on silver decorated nitrogen-doped carbon sheets ( $\mathrm{Ag} / \mathrm{NC})$. The $\mathrm{Ag} / \mathrm{NC}$ demonstrated outstanding ORR activity in contrast to nitrogen-doped carbon sheets (NC). This excellent performance was accredited to the synergistic effect between the nitrogen species and silver particles and the high amount of pyridinic nitrogen species. Moreover, Ag/NC showed excellent methanol tolerance and stability. Guo et al. [34] used a citrate-protecting method in order to prepare different loadings of silver on carbon $(\mathrm{Ag} / \mathrm{C})$ catalysts. It was reported that the ORR onset potential shifted positively with silver loading reaching upwards from (10 to 60) wt.\%.

Graphene, when decorated with silver nanoparticles, exhibits superior electronic, ionic conductivity and excellent ORR catalytic performance in alkaline media. Herein, the synthesis, characterization, and performance evaluation of $\mathrm{rGO}$ decorated with silver nanoparticles $(\mathrm{AgNP} / \mathrm{rGO})$ using simultaneous reduction of $\mathrm{GO}$ and silver ions from silver nitrate $\left(\mathrm{AgNO}_{3}\right)$ is reported. Different loadings of $\mathrm{AgNP}$ on $\mathrm{rGO}$ are attained by using different concentrations of $\mathrm{AgNO}_{3}$ precursor. The synthesized AgNP/rGO is analyzed using a rotating disk electrode (RDE) in order to investigate 
the oxygen reduction reaction (ORR) activity. Then, the AgNP/rGO is applied on tubular designed $\mathrm{ZABs}$ in order to examine the performance of ZABs.

\section{Materials and Methods}

\subsection{Synthesis and Characterization of $A g N P / r G O$}

Graphene oxide was prepared by oxidation of natural graphite powder (Sigma-Aldrich, St. Louis, MO, USA) using a modified Hummers method [35]. We mixed $2 \mathrm{~g}$ graphite powder and $2 \mathrm{~g}$ sodium nitrate $\left(\mathrm{NaNO}_{3}, \mathrm{QRëC}\right.$, Auckland, New Zealand) with $90 \mathrm{~mL}$ of sulfuric acid $\left(\mathrm{H}_{2} \mathrm{SO}_{4} 98 \%\right.$, Sigma-Aldrich) in a $1000 \mathrm{~mL}$ volumetric flask which was kept at $0-5^{\circ} \mathrm{C}$. While maintaining vigorous agitation, $12 \mathrm{~g}$ potassium permanganate $\left(\mathrm{KMnO}_{4}\right.$, QRëC, Auckland, New Zealand) was introduced slowly to the mixture in order to keep the temperature of the suspension below $5{ }^{\circ} \mathrm{C}$. After that, the suspension was transferred to a $35^{\circ} \mathrm{C}$ bath and vigorously stirred for $2 \mathrm{~h}$. After $2 \mathrm{~h}$ of stirring, the mixture was heated at $98^{\circ} \mathrm{C}$ for $10 \mathrm{~min}$. After $10 \mathrm{~min}$, an additional $200 \mathrm{~mL}$ of water was added to dilute the solution. Then, it was followed by a slow addition of $40 \mathrm{~mL}$ hydrogen peroxide $\left(\mathrm{H}_{2} \mathrm{O}_{2}\right.$ $30 \mathrm{w} / \mathrm{w} \%$, Merck KGaA, Darmstadt, Germany). Next, the solution was stirred for $1 \mathrm{~h}$. After that, the mixture was centrifuged and washed with deionized water. Finally, the resulting solid was vacuum dried at $60^{\circ} \mathrm{C}$ for more than $6 \mathrm{~h}$ and became graphene oxide (GO) powder.

The method for decoration of rGO with silver was reported by Tang et al. [29]. First, silver-ammonia solution was prepared by dropping $2 \mathrm{wt} . \%$ ammonia aqueous solution (Sigma-Aldrich) into silver nitrate solution (Sigma-Aldrich) until the brown precipitation disappeared. Accordingly, the concentration of silver nitrate solution was varied viz. $0.1 \mathrm{M}, 0.2 \mathrm{M}$ and $0.3 \mathrm{M}$. Herein, the samples obtained from $0.1 \mathrm{M}$, $0.2 \mathrm{M}$ and $0.3 \mathrm{M}$ were denoted as follows: namely, 0.1 M AgNP/rGO, 0.2 M AgNP and 0.3 M AgNP, respectively. Next, the synthesized GO powder was added to DI water $(0.5 \mathrm{mg} / \mathrm{mL})$ and then sonicated for $5 \mathrm{~min}$. Poly(vinylpyrrolidone) (PVP, Sigma-Aldrich) solution $(4 \mathrm{mg} / \mathrm{mL}, 1 \mathrm{~mL})$ was firstly mixed with GO suspension $(0.5 \mathrm{mg} / \mathrm{mL}, 10 \mathrm{~mL})$ to form a uniform mixture and glucose $(80 \mathrm{mg})$ was added. Then the mixture was stirred. When the suspension reached $60^{\circ} \mathrm{C}$, silver-ammonia solution $(1 \mathrm{~mL})$ was introduced slowly which gave AgNP/rGO. After the reaction, AgNP/rGO was centrifuged, washed with deionized water and ethanol, and then dried at $80^{\circ} \mathrm{C}$. In Figure 1a, the process of oxidation and exfoliation of graphite and simultaneous reduction of $\mathrm{GO}$ and silver ions is shown.

The synthesized $\mathrm{AgNP} / \mathrm{rGO}$ samples were examined via transmission electron microscopy (TEM, JEOL (Tokyo, Japan) JEM-1400, $100 \mathrm{kV}$ ) as well as x-ray diffraction pattern (XRD, Bruker (Billerica, Massachusetts, USA) D8-Advance, $\mathrm{Cu} \mathrm{K} \alpha$ radiation, $\lambda=1.5418 \AA$ ) operating within a $2 \theta$ range of (10 to 80) degrees. The presence of AgNP can be identified by XRD pattern and energy dispersive spectroscopy (EDS). XRD was also used to confirm the reduction of GO. The morphology of AgNP was investigated via TEM.

The ORR electrocatalytic activity of the synthesized AgNP/rGO samples was examined by a rotating disk electrode (RDE) with a potentiostat/galvanostat system (AMETEK (Berwyn, PA, USA), PAR VersaSTAT 3A). A glassy carbon electrode, $5 \mathrm{~mm}$ in diameter, was rinsed with distilled water and sonicated in acetone. Then, the samples: $0.1 \mathrm{M}$ AgNP/rGO, $0.2 \mathrm{M} \mathrm{AgNP} / \mathrm{rGO}$ and $0.3 \mathrm{M} \mathrm{AgNP} / \mathrm{rGO}$ were dropped onto the glassy carbon surface. The catalyst films were dried at $30^{\circ} \mathrm{C}$ for $1 \mathrm{~h}$. The RDE test was carried out using a three-electrode system with a glassy carbon working electrode, a silver/silver chloride $(\mathrm{Ag} / \mathrm{AgCl})$ reference electrode and a Pt plate $(20 \times 20) \mathrm{mm}$ counter electrode. $\mathrm{Ag} / \mathrm{AgCl}$ reference electrode is suitable for aqueous applications and commonly used as reference in reduction potential studies. The experiments were carried out in $0.1 \mathrm{M} \mathrm{KOH}$ solution. The solution was saturated with oxygen gas $\left(\mathrm{O}_{2}\right)$ by dispersing $\mathrm{O}_{2}$ into the solution for $30 \mathrm{~min}$ before each test. The RDE test was performed using linear sweep voltammetry in a potential range from $(0.2$ to -0.8$) \mathrm{V}$ vs. $\mathrm{Ag} / \mathrm{AgCl}$ at a scanning rate of $5 \mathrm{mV} / \mathrm{s}$ under different rotation speeds $(400,900,1600) \mathrm{rpm}$. 


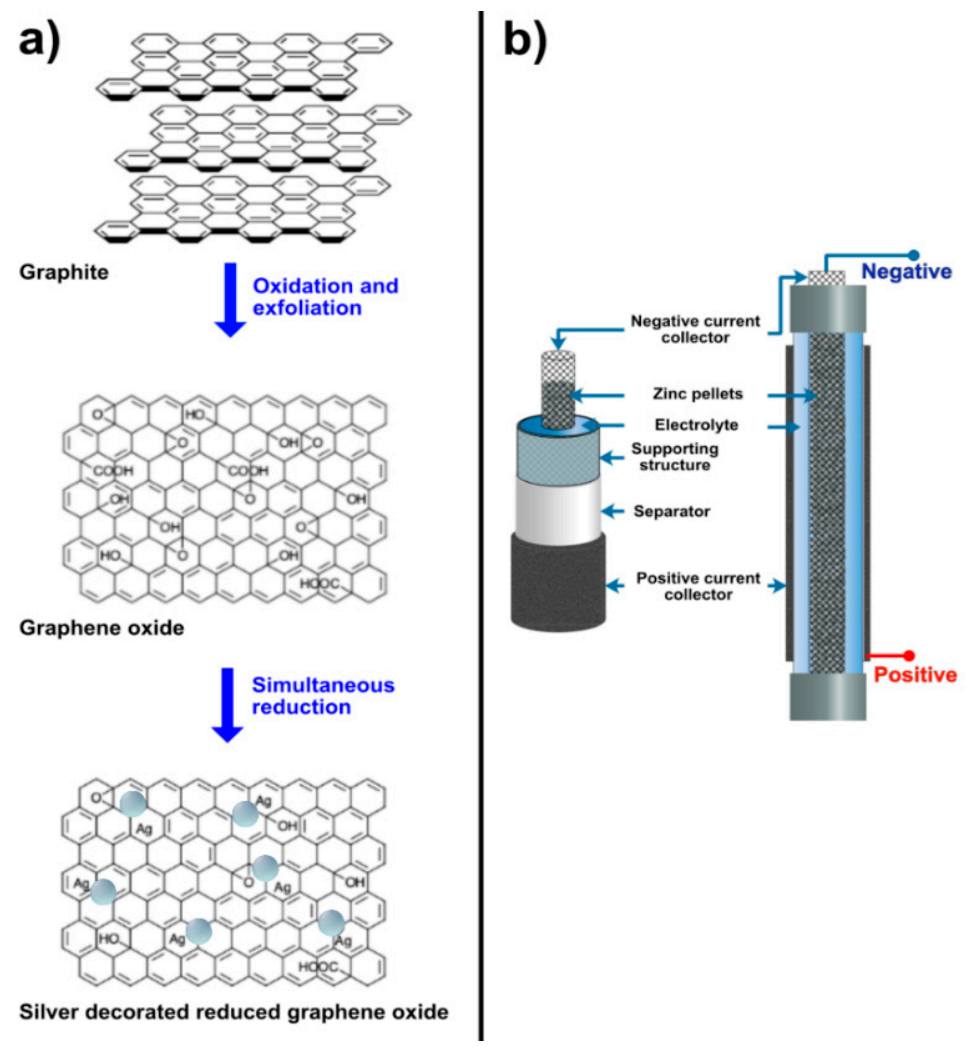

Figure 1. (a) Formation of silver nanoparticles decorated on reduced graphene oxide sheets by oxidation and exfoliation of graphite powder and simultaneous reduction of graphene oxide and silver ions, (b) a schematic diagram of the zinc-air battery.

\subsection{Fabrication and Performance Evaluation of $Z A B$}

Zinc-air batteries were produced and applied to evaluate the performance of the prepared AgNP/rGO ORR electrocatalysts. In Figure 1b, the schematic diagram of the batteries is displayed. A stainless-steel mesh cylinder, $10 \mathrm{~cm}$ long and $1 \mathrm{~cm}$ in diameter, was utilized as the structural support of the cell. Two stainless-steel tubes are attached to the cylinder at both ends. The total volume of the cell was $20 \mathrm{~cm}^{3}$. The separator was made by casting $2 \mathrm{~g}$ of $24 \mathrm{wt} . \%$ poly(vinyl acetate) (PVAc, TOA Paint Public Co., Ltd., Samut Prakan, Thailand) aqueous solution over both sides of a filter paper (No. 1 Whatman, Sigma-Aldrich) and then dried in an oven at $55{ }^{\circ} \mathrm{C}$ for $10 \mathrm{~min}$. The support cylinder was wrapped with the separator. Consequently, the cylinder was wrapped with the air-cathode, consisting of three layers: a gas diffusion layer, a cathode current collector and a catalyst layer. The catalyst layer is positioned in contact with the separator. Nickel foam $(99.97 \%, 100$ pores per inch, $1 \mathrm{~mm}$ thick, Qijing Trading Co., Ltd., Shiyan, China) was utilized as the cathode current collector. The catalyst layer was prepared by casting a slurry mixture of $1 \mathrm{~g}$ poly(tetrafluoroethylene) (PTFE, Sigma-Aldrich) powder, $0.45 \mathrm{~g}$ poly(vinyl butyral) (PVB, TOA Paint Public Co., Ltd., Samut Prakan, Thailand) and $9 \mathrm{~g}$ of the mixture between ORR catalyst $\left(\mathrm{AgNP} / \mathrm{rGO}\right.$ or manganese oxide $\left(\mathrm{MnO}_{2}\right.$, Sigma-Aldrich) and carbon black (Vulcan ${ }^{\circledR}$ XC-72, Cabot Corporation, Boston, MA, USA) in $10 \mathrm{~mL}$ ethanol on one side of the nickel foam. The varying weight ratios of AgNP/rGO to carbon black were 9:0, 7:2, 5:4 and 3:6, while the weight ratio of $\mathrm{MnO}_{2}$ to carbon black was $2: 7$. In total $1 \mathrm{~g}$ of the slurry was deposited on the nickel foam. The gas diffusion layer was fabricated on the other side of the nickel foam by casting a slurry mixture of $3 \mathrm{~g}$ carbon black, $7 \mathrm{~g}$ PTFE powder, and $0.5 \mathrm{~g}$ PVB in $10 \mathrm{~mL}$ of ethanol. Absolutely $1 \mathrm{~g}$ of the slurry was deposited on this side of the nickel foam. The coated nickel foam was then heat-pressed at $350^{\circ} \mathrm{C}$ for $5 \mathrm{~min}$ using a manual hot press machine. The gas diffusion layer revealed hydrophobicity and kept the electrolyte inside the cell whilst enabling oxygen gas to diffuse 
to the catalyst layer. Besides, the hydrophobicity of the gas diffusion layer prevented leakage of the electrolyte and water flooding in the cathode.

Another stainless-steel mesh cylinder with $0.45 \mathrm{~cm}$ diameter was used as the anode current collector. The anode current collector was inserted inside the structural support cylinder. The anode made of $10 \mathrm{~g}$ zinc granules (99\%, $\varnothing=0.8 \mathrm{~mm}$, Sirikul Engineering Ltd., Part., Samut Prakan, Thailand) was packed inside the anode current collector. The electrolyte of $8 \mathrm{M} \mathrm{KOH}$ aqueous solution, with a total volume of $15 \mathrm{~mL}$, was fed to the cell.

The polarization characteristics of the batteries were analyzed by a battery analyzer MC2020, Battery Metric, Toronto, ON, Canada). The discharge potentials of the battery were recorded point-by-point while the discharge current density of the battery was stepped up from $0 \mathrm{~mA} / \mathrm{cm}^{2}$ upwards. At each point, the battery was held for $5 \mathrm{~s}$ to allow the system to reach equilibrium potential. In addition, the $\mathrm{Ag} / \mathrm{AgCl}$ reference electrode was placed inside the cell in order to measure the overpotential of the air cathode.

\section{Results and Discussion}

\subsection{Characterization of $A g N P / r G O$ Samples}

As shown in Figure 1a, the desired AgNP/rGO sheets were obtained by exfoliation and oxidation of graphite powder and followed by simultaneous reduction of GO and silver ions using glucose at $60^{\circ} \mathrm{C}$. Both the crystalline nature and phase structure of the synthesized samples were determined by $\mathrm{XRD}$ analysis (Figure 2). All AgNP/rGO samples displayed a broad peak at $25.4^{\circ}$ corresponding to the (002) plane of rGO [36] which confirmed that GO was successfully reduced to rGO. In addition, the peaks observed at $38.1^{\circ}, 44.3^{\circ}$ and $64.5^{\circ}$ corresponded to the (111), (200) and (220) crystallographic planes of the AgNP phase according to JCPDS no. 04-0783 [37]. These reflections indicated that the structure of AgNP was a face-centered cubic structure. No crystal impurity peaks were observed, which indicated high purity of the samples. Results confirmed that the samples consisted of AgNP decorated on $\mathrm{rGO}$. After forming $\mathrm{AgNP} / \mathrm{rGO}$, the crystalline structure of the silver was barely affected. Thus, it was verified that the oxygen-containing groups of $\mathrm{GO}$ could adsorb $\mathrm{Ag}\left(\mathrm{NH}_{3}\right)_{2}{ }^{+}$by electrostatic interaction and then these ions could be reduced by the addition of glucose. However, the pinning force, supplied by the oxygen-containing groups, could hinder the movement and recrystallization of the AgNP generated on the rGO sheets [38]. The average crystallite size of the AgNP estimated by the Debye-Scherrer formula [39] was found to be in the range of 5-10 nm. In each sample, the silver content was determined by EDS. Based on the EDS results, $0.1 \mathrm{M} \mathrm{AgNP} / \mathrm{rGO}, 0.2 \mathrm{M}$ AgNP/rGO and $0.3 \mathrm{M} \mathrm{AgNP} / \mathrm{rGO}$ showed an average percentage of $\mathrm{Ag} 10.2 \mathrm{wt} . \%, 18.6 \mathrm{wt} . \%$ and $28.0 \mathrm{wt} . \%$, respectively.

The morphology of AgNP decorated onto rGO sheets was investigated via TEM (Figure 3). Thus, it can be seen in Figure 3a-c that silver nanoparticles were homogeneously distributed over the surface of rGO sheets without obvious aggregation. The samples showed several small AgNP uniformly distributed on the substrates. The AgNP were mostly distributed between 3 and $8 \mathrm{~nm}$, and the mean particle size diameter was $5 \mathrm{~nm}$. The size of AgNP observed was in line with the size estimated from XRD analysis. In Figure 3c, the sample 0.3 M AgNP/rGO displayed the highest number of tiny AgNP which were well dispersed on the rGO sheets. 


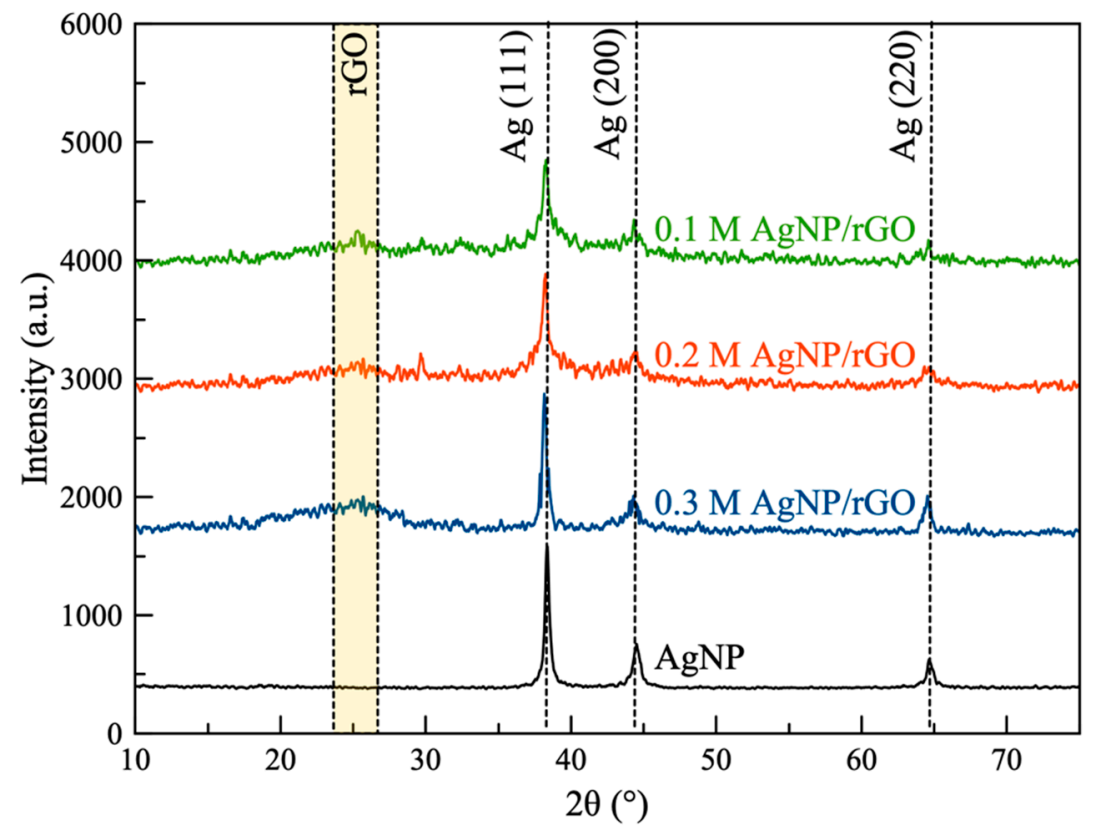

Figure 2. XRD pattern of the synthesized samples: 0.1 M silver nanoparticles (AgNP)/reduced graphene oxide (rGO), 0.2 M AgNP/rGO and 0.3 M AgNP/rGO and silver nanoparticles (AgNP).

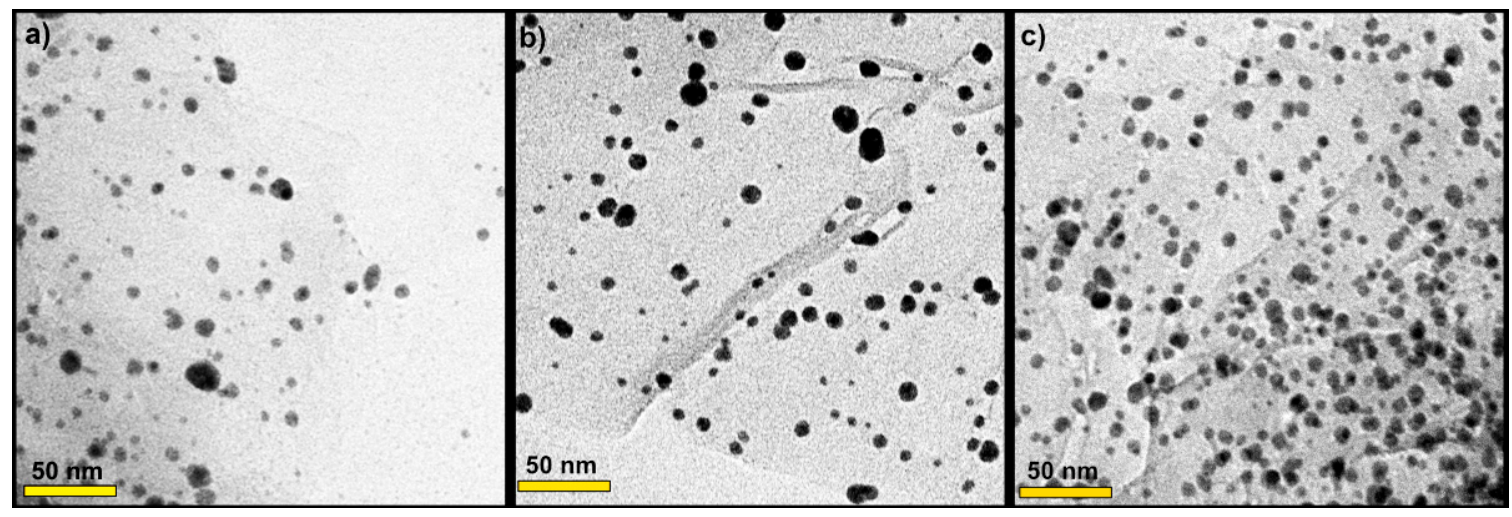

Figure 3. TEM images of the prepared samples: (a) $0.1 \mathrm{M} \mathrm{AgNP} / \mathrm{rGO}$, (b) $0.2 \mathrm{M} \mathrm{AgNP} / \mathrm{rGO}$ and (c) $0.3 \mathrm{M} \mathrm{AgNP} / \mathrm{rGO}$.

\subsection{ORR Electrochemical Performance of AgNP/rGO Samples}

In Figure 4, the linear scan voltammograms for ORR using different AgNP/rGO samples at different rotating speeds 400, 900, and $1600 \mathrm{rpm}$ are shown. Also, the inset shows a magnified part of the original plot at $1600 \mathrm{rpm}$. The electrode using rGO without silver exhibited the lowest ORR performance. Also, its linear scan voltammograms show insignificant change with respect to the change in rotating speed. For $0.1 \mathrm{AgNP} / \mathrm{rGO}, 0.2 \mathrm{AgNP} / \mathrm{rGO}$ and $0.3 \mathrm{AgNP} / \mathrm{rGO}$ electrodes, it can clearly be seen that the limiting diffusion current of all samples increased when rotating speed increased. The electrode using $0.3 \mathrm{AgNP} / \mathrm{rGO}$ exhibited the less negative onset potential, while the $0.1 \mathrm{AgNP} / \mathrm{rGO}$ electrode was found to have its oxygen reduction at most negative potential. Further, it is noted that the $0.3 \mathrm{AgNP} / \mathrm{rGO}$ electrode showed larger limiting current density and more positive half-wave potential compared to the $0.2 \mathrm{AgNP} / \mathrm{rGO}$ and $0.1 \mathrm{AgNP} / \mathrm{rGO}$ electrodes. More positive onset potential, more positive half-wave potential and greater limiting current of the $0.3 \mathrm{AgNP} / \mathrm{rGO}$ electrode for oxygen reduction compared to the $0.2 \mathrm{AgNP} / \mathrm{rGO}$, and $0.1 \mathrm{AgNP} / \mathrm{rGO}$ electrodes demonstrated that the higher $\mathrm{Ag}$ content resulted in increased electrocatalytic activity towards ORR. This further confirms that the decoration of AgNP on rGO sheets significantly boosted its electroactive performance towards ORR. 


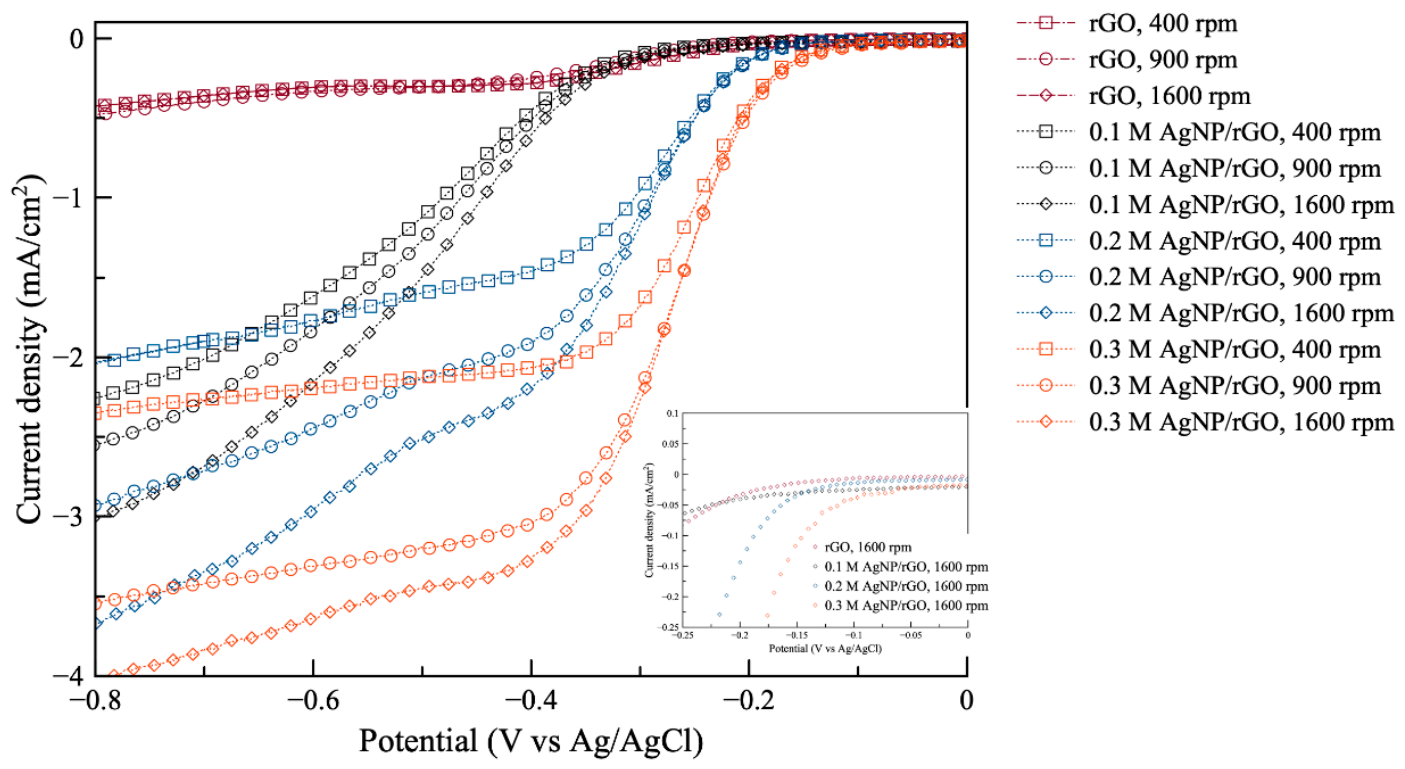

Figure 4. Oxygen reduction reaction (ORR) polarization curves of the prepared samples: rGO, $0.1 \mathrm{M}$ AgNP/rGO, 0.2 M AgNP/rGO, and 0.3 M AgNP/rGO at 400, 900, $1600 \mathrm{rpm}$. The inset shows a magnified part of the original plot.

ORR is a complicated and multi-step reaction process capable of proceeding through multiple pathways. Oxygen can be reduced to $\mathrm{OH}^{-}$by a four-electron pathway, as exhibited in Equation (1), or to $\mathrm{HO}_{2}{ }^{-}$by a two-electron pathway and further reduce to $\mathrm{OH}^{-}$, as presented in Equations (2) and (3):

$$
\begin{gathered}
\mathrm{O}_{2}+2 \mathrm{H}_{2} \mathrm{O}+4 e^{-} \rightarrow 4 \mathrm{OH}^{-} \\
\mathrm{O}_{2}+\mathrm{H}_{2} \mathrm{O}+2 e^{-} \rightarrow \mathrm{HO}_{2}^{-}+\mathrm{OH}^{-} \\
\mathrm{HO}_{2}^{-}+\mathrm{H}_{2} \mathrm{O}+2 e^{-} \rightarrow 3 \mathrm{OH}^{-}
\end{gathered}
$$

Koutecky-Levich equation was applied to determine the number of electron transfer per oxygen molecule for oxygen reduction [40], as shown accordingly in Equation (4):

$$
\frac{1}{j}=\frac{1}{j_{k}}+\frac{1}{B \omega^{1 / 2}},
$$

where $j$ is the total current density, $j_{k}$ is the kinetic current density, and $\omega$ is the electrode rotation speed. The coefficient $B$ is determined from the slope of the Koutecky-Levich plots by expressing the linear relationship between $j^{-1}$ and $\omega^{-1 / 2}$. Then, the Levich equation was applied to determine the number of electron transfer ( $n)$, as shown in Equation (5):

$$
B=0.2 n \mathrm{FD}_{\mathrm{O}_{2}}^{2 / 3} v^{-1 / 6} \mathrm{C}_{\mathrm{O}_{2}},
$$

where $n$ is the number of electrons transferred per oxygen molecule. $\mathrm{F}$ is $96,485 \mathrm{C} \mathrm{mol}^{-1}$ (the Faraday constant). $D_{\mathrm{O}_{2}}$ is the diffusion coefficient of oxygen gas in $0.1 \mathrm{M} \mathrm{KOH}$, which is $\left(1.9 \times 10^{-5}\right) \mathrm{cm}^{2} \mathrm{~s}^{-1}, v$ is the kinetic viscosity $\left(0.01 \mathrm{~cm}^{2} \mathrm{~s}^{-1}\right)$, and $C_{\mathrm{O}_{2}}$ is the concentration of $\mathrm{O}_{2}\left(1.2 \times 10^{-6} \mathrm{~mol} \mathrm{~cm}^{-3}\right)$. It is noted that the rotation speed $(\omega)$ is represented in rpm. Table 1 presents important data extracted from Figure 4. It is noted that the electrode using rGO without silver is not included as it showed very low ORR performance. 
Table 1. Electrochemical data (at $1600 \mathrm{rpm}$ ) for $0.1 \mathrm{M}$ AgNP/rGO, $0.2 \mathrm{M} \mathrm{AgNP} / \mathrm{rGO}$ and $0.3 \mathrm{M}$ $\mathrm{AgNP} / \mathrm{rGO}$ extracted from linear scan voltammograms, as shown in Figure 4.

\begin{tabular}{|c|c|c|c|}
\hline Samples & $\begin{array}{l}\text { Current Density }\left(\mathrm{mA} \mathrm{cm}^{-2}\right) \\
\text { at }-0.4 \mathrm{~V} \text { vs. } \mathrm{Ag} / \mathrm{AgCl}\end{array}$ & $\begin{array}{c}\text { Onset Potential (V vs. } \\
\mathrm{Ag} / \mathrm{AgCl})\end{array}$ & $\begin{array}{l}\text { The Number of } \\
\text { Electron Transfer }\end{array}$ \\
\hline $0.1 \mathrm{M}$ AgNP/rGO & -0.63 & -0.21 & 2.79 \\
\hline $0.2 \mathrm{M}$ AgNP/rGO & -2.20 & -0.15 & 3.68 \\
\hline $0.3 \mathrm{M}$ AgNP/rGO & -3.28 & -0.11 & 3.92 \\
\hline
\end{tabular}

It is known that, in an alkaline solution, oxygen is either reduced to $\mathrm{HO}_{2}{ }^{-}$as an intermediate through a two-electron pathway, followed by further reduction to $\mathrm{OH}^{-}$, or it can be reduced to $\mathrm{OH}^{-}$ through a four-electron pathway. The latter is more efficient and favorable for zinc-air batteries.

According to the three different samples: $0.1 \mathrm{M}$ AgNP/rGO (10.2 wt.\% Ag loading), $0.2 \mathrm{M}$ AgNP/rGO (18.6 wt.\% Ag loading) and 0.3 M AgNP/rGO (28.0 wt.\% Ag loading), the number of electrons transferred at $-0.4 \mathrm{~V}$ vs. $\mathrm{Ag} / \mathrm{AgCl}$ and $1600 \mathrm{rpm}$ was found to be 2.79, 3.68 and 3.92, respectively. For the $0.1 \mathrm{M} \mathrm{AgNP} / \mathrm{rGO}$ sample, the number of electron transfer being 2.79 was seen to be closer to the two-electron pathway than to the four-electron pathway. In contrast, regarding the $0.2 \mathrm{M} \mathrm{AgNP} / \mathrm{rGO}$ and $0.3 \mathrm{M} \mathrm{AgNP} / \mathrm{rGO}$ samples, the ORR mechanism was seen to be more favorable to the four-electron pathway. Specifically, the number of electron transfer for the $0.3 \mathrm{M} \mathrm{AgNP} / \mathrm{rGO}$ sample favored the four-electron pathway more than the others on account of the increasing amount of AgNP, as observed from EDS and TEM results. Lim et al. [31] reported that the loading of high amount of silver and good distribution generates good ORR catalytic performance. Herein, the number of electron transfer reached four, which corresponded to the result obtained in the present work. By increasing the amount of silver, the number of electrons transferred became closer to four; increasing the amount of AgNP also increased the number of active sites, which resulted in higher activity [41]. Although the silver loading in this work was less than what Lim et al. [31] reported, the result is not much different. It is evident, therefore, that loading silver of $28 \mathrm{wt} . \%$ was sufficient to produce a direct four-electron pathway. ORR activity depends on several parameters such as the amount of silver loading, the particle size of silver nanoparticles, and the distribution of silver particles on the rGO sheets. However, in this work, the ORR activity mainly depends on the quantity and distribution of silver particles because the particle size of silver in the three samples are very similar.

\subsection{Performances of ZAB Using the Synthesized AgNP/rGO Electrocatalyst}

As regards air cathode polarization, the zinc-air battery was fabricated using the $0.3 \mathrm{M} \mathrm{AgNP} / \mathrm{rGO}$ catalyst with different ratios of AgNP/rGO to carbon black: namely, 9:0, 7:2, 5:4 and 3:6. The air-cathode made of $\mathrm{MnO}_{2}$ to carbon black of 2:7, which is generally used as ORR electrocatalyst [42,43], was also included, as a reference, to compare the performance of the synthesized electrocatalysts. Figure 5 a shows the overpotential of the air cathodes. Initially, in all cases, the overpotential dropped significantly. Then, it linearly decreased with discharge current density. The highest current density was obtained using the 9:0 AgNP/rGO cathode. The latter exhibited the current density of $410 \mathrm{~mA} \mathrm{~cm}^{-2}$ at overpotential of $-0.8 \mathrm{~V}$ while the air-cathode made of $2: 7 \mathrm{MnO}_{2}$ showed the current density of $200 \mathrm{~mA} \mathrm{~cm}{ }^{-2}$ at overpotential of $-0.8 \mathrm{~V}$. When the $\mathrm{AgNP} / \mathrm{rGO}$ were mixed with conductive carbon additive, they showed a higher overpotential as compared to the 9:0 AgNP/rGO cathode. Consequently, the cathode using 9:0 AgNP/rGO was implemented in ZAB for measuring battery performance. 

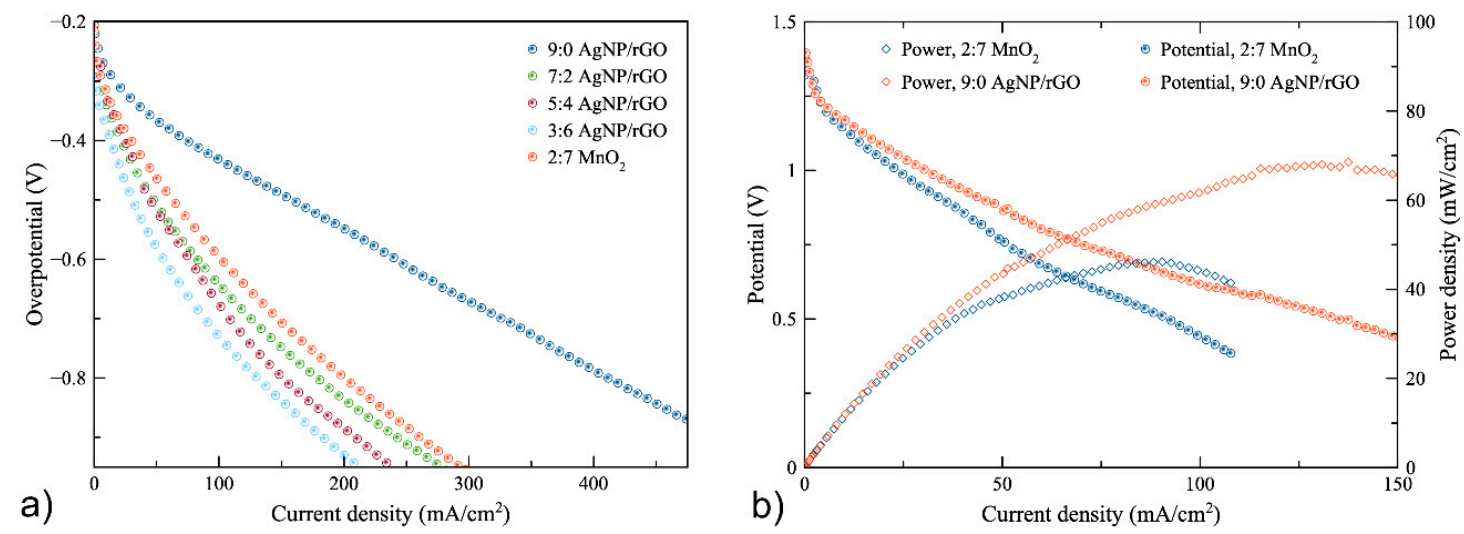

Figure 5. (a) overpotential of the 9:0, 7:2, 5:4 and 3:6 AgNP/rGO air-cathodes and the 2:7 $\mathrm{MnO}_{2}$ air-cathode (b) polarization characteristics of the zinc-air batteries using the 9:0 AgNP/rGO cathode and the 2:7 $\mathrm{MnO}_{2}$ cathode.

The batteries were examined for polarization characteristics. In Figure $5 b$, discharge polarization curves are shown for the performance of $\mathrm{ZABs}$ with the $\mathrm{AgNP} / \mathrm{rGO}$ and $\mathrm{MnO}_{2}$ cathodes. Generally, the discharge voltage of battery depends on the battery state of charge and the discharge current density. In this study, the battery had a zinc electrode with an excess capacity, therefore the battery state of charge remained constant throughout the polarization test. Consequently, the discharge voltage was a function of discharge current density. The performance of the battery solely depended on the air-electrode. During discharge, the zinc anode dissolves in the electrolyte to form zincate ions $\left(\left[\mathrm{Zn}(\mathrm{OH})_{4}\right]^{2-}\right)$, releasing electrons flowing to the cathode via an external circuit. The corresponding reaction at the anode is as shown in Equation (6):

$$
\mathrm{Zn}+4 \mathrm{OH}^{-} \rightarrow\left[\mathrm{Zn}(\mathrm{OH})_{4}\right]^{2-}+2 e^{-}
$$

The results, as plotted in Figure $5 b$, revealed that the battery with the AgNP/rGO air-cathode was seen to perform much better than the battery with the $\mathrm{MnO}_{2}$ air-cathode. The open-circuit voltages of $\mathrm{AgNP} / \mathrm{rGO}$ and $\mathrm{MnO}_{2}$ batteries were $1.40 \mathrm{~V}$ and $1.38 \mathrm{~V}$, respectively. When the discharge current increased, the potential of both batteries slowly dropped linearly due to ohmic loss. At $1 \mathrm{~V}$, the current densities of the batteries with the AgNP/rGO and $\mathrm{MnO}_{2}$ catalysts were found to be 32.5 and $20 \mathrm{~mA} \mathrm{~cm}^{-2}$, respectively. The potential of the battery using $\mathrm{MnO}_{2}$ dropped to $0.388 \mathrm{~V}$ at $107 \mathrm{~mA} \mathrm{~cm}^{-2}$. In comparison, the potential of the battery using AgNP/rGO dropped to $0.435 \mathrm{~V}$ at $150 \mathrm{~mA} \mathrm{~cm}{ }^{-2}$. The higher current density value of $\mathrm{AgNP} / \mathrm{rGO}$ was due to the higher ORR catalytic performance. The maximum current densities of the batteries using $\mathrm{AgNP} / \mathrm{rGO}$ and $\mathrm{MnO}_{2}$ were 150 and $107 \mathrm{~mA} \mathrm{~cm}^{-2}$, respectively. In addition, the peak power densities of the batteries with AgNPs/rGO and $\mathrm{MnO}_{2}$ reached $68 \mathrm{~mW} \mathrm{~cm}{ }^{-2}$ at $130 \mathrm{~mA} \mathrm{~cm}^{-2}$ and $46 \mathrm{~mW} \mathrm{~cm}^{-2}$ at $90 \mathrm{~mA} \mathrm{~cm}^{-2}$, respectively. Thus, the power density of the battery with the AgNP/rGO catalyst proved to be higher than the battery with the $\mathrm{MnO}_{2}$ catalyst, as confirmed by the results of the cathodic polarization. In conclusion, the battery that used the synthesized AgNP/rGO catalyst as an ORR electrocatalyst exhibited better performance than the battery using $\mathrm{MnO}_{2}$ as an ORR electrocatalyst. Table 2 shows a comparison of the battery that used the synthesized AgNP/rGO catalyst and other zinc-air batteries previously reported. The battery using the $\mathrm{AgNP} / \mathrm{rGO}$ catalyst showed a higher performance. However, results may differ depending on different conditions in the experiment. 
Table 2. Comparison of the battery that used the synthesized catalyst (0.3 M AgNP/rGO) and other zinc-air batteries previously reported.

\begin{tabular}{|c|c|c|c|c|}
\hline Air Cathode & Anode/Electrolyte & $\begin{array}{l}\text { Potential (V)/Current } \\
\text { Density }\left(\mathrm{mA} \mathrm{cm}^{-2}\right) @ \\
\text { Peak Power Density }\end{array}$ & $\begin{array}{l}\text { Peak Power } \\
\text { Density } \\
\left(\mathrm{mW} \mathrm{cm}^{-2}\right)\end{array}$ & References \\
\hline $\mathrm{AgNP} / \mathrm{rGO}$ & Zn granular/8 M KOH & $0.52 / 130$ & 68 & This work \\
\hline $\mathrm{MnO}_{2}$ & Zn granular/8 M KOH & $0.51 / 90$ & 46 & This work \\
\hline $\mathrm{MnO}_{2}$ on carbon paper & Zn sheet/6 M KOH & $0.5 / 30$ & 19.5 & [44] \\
\hline$\alpha-\mathrm{MnO}_{2}-\mathrm{LaNiO}_{3} / \mathrm{CNT}$ & $\begin{array}{c}\text { Zn plate } / 6 \mathrm{M} \mathrm{KOH} \mathrm{+} \\
0.4 \mathrm{M} \mathrm{ZnO}\end{array}$ & $0.6 / 81$ & 55.1 & [45] \\
\hline
\end{tabular}

Stability of the air cathode using the synthesized catalyst ( $0.3 \mathrm{M} \mathrm{AgNP/rGO})$ was examined. The battery was filled initially with $10 \mathrm{~g}$ of zinc granules and $15 \mathrm{~mL}$ electrolyte. The battery was then discharged at the discharge rate of $25 \mathrm{~mA} \mathrm{~cm}^{-2}$ until the discharge potential reached $0.7 \mathrm{~V}$. The battery was then disconnected, cleaned and replaced with new zinc granules and fresh electrolyte. Three repetitions of discharge test were conducted. As shown in Figure 6, the galvanostatic discharge characteristics of the battery are displayed. In the first test, the battery exhibited discharge plateau at (1.05-0.99) $\mathrm{V}$ for discharge capacity of $717.5 \mathrm{mAh} \mathrm{g}_{\mathrm{Zn}}{ }^{-1}$. Moreover, the discharge characteristics of the second and third tests were like the first test. The second and the third tests exhibited discharge capacities of 722.1 and $719.6 \mathrm{mAh} \mathrm{g}_{\mathrm{Zn}}{ }^{-1}$, respectively. The significant degradation of the battery was not observed. Results demonstrated excellent stability of the air cathode.

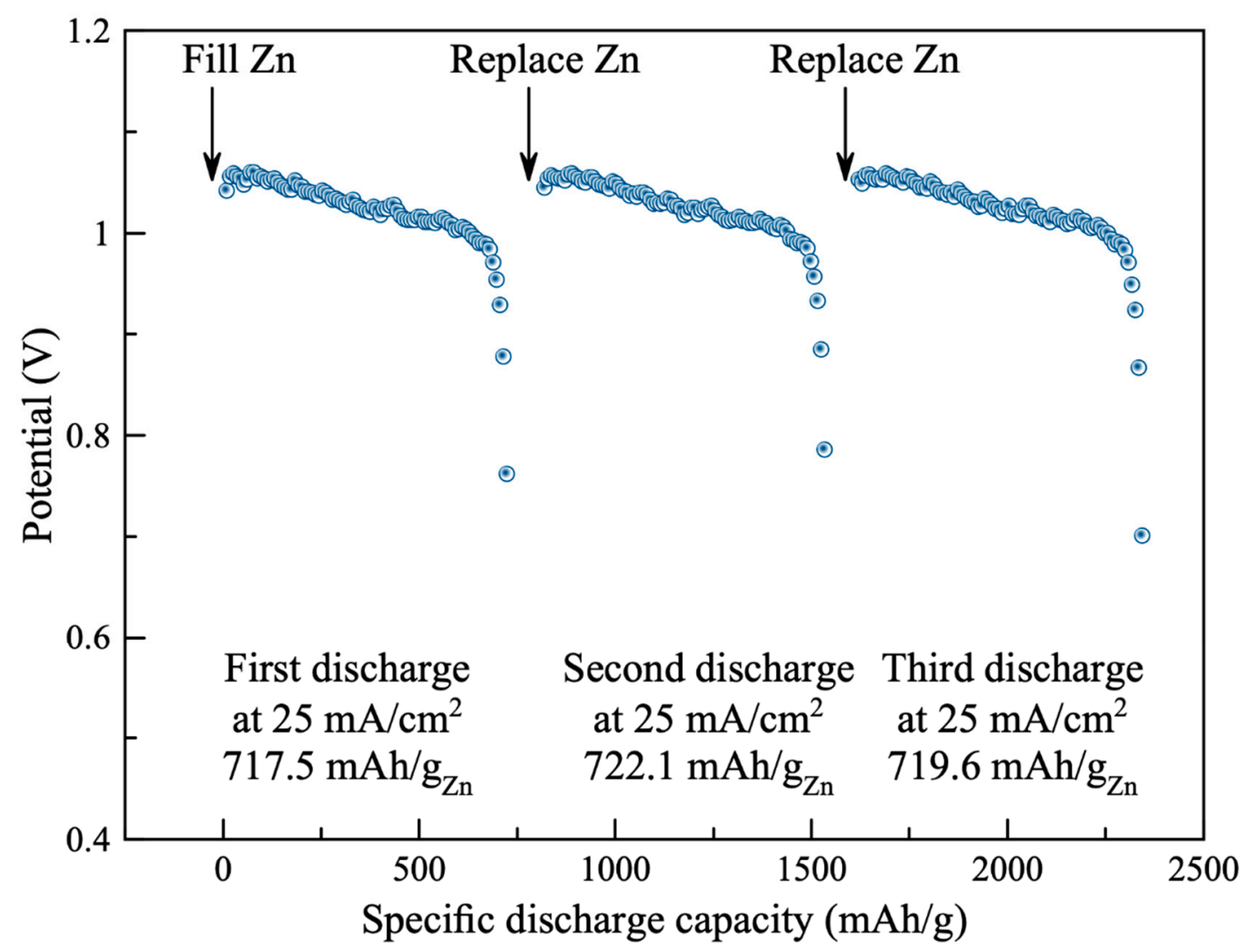

Figure 6. Stability and discharge capacity of the battery that used the synthesized catalyst $(0.3 \mathrm{M}$ $\mathrm{AgNP} / \mathrm{rGO}$ ).

\section{Conclusions}

This work focused on the development of a cost-effective ORR electrocatalyst for a zinc-air battery. Thus, AgNP/rGO was synthesized via oxidation and exfoliation of graphite powder and followed by 
simultaneous reduction of graphene oxide and silver ions. The small and uniformly dispersed AgNP offered a large surface area of active sites for the ORR. Loading silver of $28 \mathrm{wt}$ \% proved sufficient to produce a four-electron pathway. It was significant that the air cathode made of $\mathrm{AgNP} / \mathrm{rGO}$ without addition of carbon black exhibited the smallest overpotential and performed much better than the $\mathrm{MnO}_{2}$ catalyst. Hence, the battery with the AgNP/rGO catalyst reached the maximum current density of $150 \mathrm{~mA} \mathrm{~cm}^{-2}$ at $0.435 \mathrm{~V}$ and peak power of $68 \mathrm{~mW} \mathrm{~cm}^{-2}$ at $130 \mathrm{~mA} \mathrm{~cm}^{-2}$.

Author Contributions: Conceptualization, S.K.; methodology, S.K.; investigation, L.P. and W.K.-i.; formal analysis, L.P., S.K., A.S., F.M., T.Y., M.T.N.; writing-original draft preparation, S.K.; writing-review and editing, A.S., F.M., T.Y., M.T.N. and S.K.; supervision, S.K.; funding acquisition, S.K.; project administration, S.K. All authors have read and agreed to the published version of the manuscript.

Funding: Chulalongkorn Academic Advancement into its Second Century Project, Grant for Join Funding, Ratchadaphiseksomphot Endowment Fund, and the Energy Storage Cluster of Chulalongkorn University are acknowledged.

Acknowledgments: The authors thank Kijchai Kanjanapaparkul for his dedicated help in equipment setup. S.K. thanks Hokkaido University for financial support for his stay in Sapporo.

Conflicts of Interest: The authors declare no potential conflict of interest.

\section{Abbreviations}

$\begin{array}{ll}\text { ZAB } & \text { Zinc-air battery } \\ \text { ORR } & \text { Oxygen reduction reaction } \\ \text { AgNP/rGO } & \text { Silver nanoparticle decorated on reduced graphene oxide } \\ \text { EES } & \text { Electrical energy storage } \\ \text { LIB } & \text { Lithium-ion battery } \\ \text { rGO } & \text { Reduced graphene oxide } \\ \text { GO } & \text { Graphene oxide } \\ \text { AgNP } & \text { Silver nanoparticle } \\ \text { Ag/N-rGO } & \text { Silver decorated on nitrogen-doped reduced graphene oxide } \\ \text { Pt/C } & \text { Platinum on carbon } \\ \text { Ag/NC } & \text { Silver decorated on nitrogen-doped carbon sheet } \\ \text { TEM } & \text { Transmission electron microscope } \\ \text { XRD } & \text { X-ray diffraction } \\ \text { EDS } & \text { Energy dispersive spectroscopy } \\ \text { RDE } & \text { Rotating disk electrode } \\ \text { PVP } & \text { Poly(vinylpyrrolidone) } \\ \text { PVAc } & \text { Poly(vinyl acetate) } \\ \text { PVB } & \text { Poly(vinyl butyral) } \\ \text { PTFE } & \text { Poly(tetrafluoroethylene) }\end{array}$

\section{References}

1. Kloppenburg, S.; Smale, R.; Verkade, N. Technologies of Engagement: How Battery Storage Technologies Shape Householder Participation in Energy Transitions. Energies 2019, 12, 4384. [CrossRef]

2. Larcher, D.; Tarascon, J.M. Towards greener and more sustainable batteries for electrical energy storage. Nat. Chem. 2014, 7, 19. [CrossRef] [PubMed]

3. Winter, M.; Barnett, B.; Xu, K. Before Li Ion Batteries. Chem. Rev. 2018, 118, 11433-11456. [CrossRef] [PubMed]

4. Wu, X.; Song, K.; Zhang, X.; Hu, N.; Li, L.; Li, W.; Zhang, L.; Zhang, H. Safety Issues in Lithium Ion Batteries: Materials and Cell Design. Front. Energy Res. 2019, 7. [CrossRef]

5. Ouyang, D.; Chen, M.; Huang, Q.; Weng, J.; Wang, Z.; Wang, J. A Review on the Thermal Hazards of the Lithium-Ion Battery and the Corresponding Countermeasures. Appl. Sci. 2019, 9, 2483. [CrossRef]

6. Ould Ely, T.; Kamzabek, D.; Chakraborty, D. Batteries Safety: Recent Progress and Current Challenges. Front. Energy Res. 2019, 7. [CrossRef] 
7. Zhang, J.; Zhou, Q.; Tang, Y.; Zhang, L.; Li, Y. Zinc-air batteries: are they ready for prime time? Chem. Sci. 2019, 10, 8924-8929. [CrossRef]

8. Lao-atiman, W.; Bumroongsil, K.; Arpornwichanop, A.; Bumroongsakulsawat, P.; Olaru, S.; Kheawhom, S. Model-Based Analysis of an Integrated Zinc-Air Flow Battery/Zinc Electrolyzer System. Front. Energy Res. 2019, 7. [CrossRef]

9. Abbasi, A.; Hosseini, S.; Somwangthanaroj, A.; Mohamad, A.A.; Kheawhom, S. Poly(2,6-Dimethyl-1, 4-Phenylene Oxide)-Based Hydroxide Exchange Separator Membranes for Zinc-Air Battery. Int. J. Mol. Sci. 2019, 20, 3678. [CrossRef]

10. Hosseini, S.; Abbasi, A.; Uginet, L.-O.; Haustraete, N.; Praserthdam, S.; Yonezawa, T.; Kheawhom, S. The Influence of Dimethyl Sulfoxide as Electrolyte Additive on Anodic Dissolution of Alkaline Zinc-Air Flow Battery. Sci. Rep. 2019, 9, 14958. [CrossRef]

11. Li, H.; Ma, L.; Han, C.; Wang, Z.; Liu, Z.; Tang, Z.; Zhi, C. Advanced rechargeable zinc-based batteries: Recent progress and future perspectives. Nano Energy 2019, 62, 550-587. [CrossRef]

12. Kao-ian, W.; Pornprasertsuk, R.; Thamyongkit, P.; Maiyalagan, T.; Kheawhom, S. Rechargeable Zinc-Ion Battery Based on Choline Chloride-Urea Deep Eutectic Solvent. J. Electrochem. Soc. 2019, 166, A1063-A1069. [CrossRef]

13. Van Genderen, E.; Wildnauer, M.; Santero, N.; Sidi, N. A global life cycle assessment for primary zinc production. Int. J. Life Cycle Assess. 2016, 21, 1580-1593. [CrossRef]

14. Wang, C.; Yu, Y.; Niu, J.; Liu, Y.; Bridges, D.; Liu, X.; Pooran, J.; Zhang, Y.; Hu, A. Recent Progress of Metal-Air Batteries-A Mini Review. Appl. Sci. 2019, 9, 2787. [CrossRef]

15. Caramia, V.; Bozzini, B. Materials science aspects of zinc-air batteries: A review. Mater. Renew. Sustain. Energy 2014, 3, 28. [CrossRef]

16. Pan, J.; Xu, Y.Y.; Yang, H.; Dong, Z.; Liu, H.; Xia, B.Y. Advanced Architectures and Relatives of Air Electrodes in Zn-Air Batteries. Adv. Sci. 2018, 5, 1700691. [CrossRef]

17. Ma, R.; Lin, G.; Zhou, Y.; Liu, Q.; Zhang, T.; Shan, G.; Yang, M.; Wang, J. A review of oxygen reduction mechanisms for metal-free carbon-based electrocatalysts. NPJ Comput. Mater. 2019, 5, 78. [CrossRef]

18. Wieckowski, A.; Spendelow, J. Oxygen Reduction Reaction in Alkaline Solution. In Encyclopedia of Applied Electrochemistry; Kreysa, G., Ota, K.-I., Savinell, R.F., Eds.; Springer: New York, NY, USA, 2014; pp. 1491-1496. [CrossRef]

19. Higuchi, K.; Sugiyama, H.; Kubota, J. Molecular and Dissociative Adsorption of Oxygen on Solid Oxide

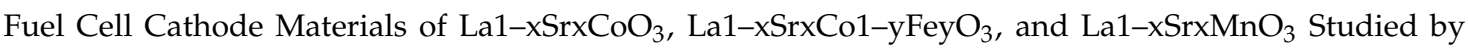
Temperature-Programmed Desorption. J. Phys. Chem. C 2017, 121, 14581-14588. [CrossRef]

20. Nie, Y.; Li, L.; Wei, Z. Recent advancements in Pt and Pt-free catalysts for oxygen reduction reaction. Chem. Soc. Rev. 2015, 44, 2168-2201. [CrossRef]

21. Erikson, H.; Sarapuu, A.; Tammeveski, K. Oxygen Reduction Reaction on Silver Catalysts in Alkaline Media: a Minireview. ChemElectroChem 2019, 6, 73-86. [CrossRef]

22. Qaseem, A.; Chen, F.; Wu, X.; Johnston, R.L. Pt-free silver nanoalloy electrocatalysts for oxygen reduction reaction in alkaline media. Catal. Sci. Technol. 2016, 6, 3317-3340. [CrossRef]

23. Lee, X.J.; Hiew, B.Y.Z.; Lai, K.C.; Lee, L.Y.; Gan, S.; Thangalazhy-Gopakumar, S.; Rigby, S. Review on graphene and its derivatives: Synthesis methods and potential industrial implementation. J. Taiwan Inst. Chem. Eng. 2019, 98, 163-180. [CrossRef]

24. Guo, X.; Lu, G.; Chen, J. Graphene-Based Materials for Photoanodes in Dye-Sensitized Solar Cells. Front. Energy Res. 2015, 3. [CrossRef]

25. Begum, A.; Bose, M.; Moula, G. Graphene Supported Rhodium Nanoparticles for Enhanced Electrocatalytic Hydrogen Evolution Reaction. Sci. Rep. 2019, 9, 17027. [CrossRef] [PubMed]

26. García-Miranda Ferrari, A.; Brownson, D.A.C.; Banks, C.E. Investigating the Integrity of Graphene towards the Electrochemical Hydrogen Evolution Reaction (HER). Sci. Rep. 2019, 9, 15961. [CrossRef]

27. Brownson, D.A.C.; Smith, G.C.; Banks, C.E. Graphene oxide electrochemistry: the electrochemistry of graphene oxide modified electrodes reveals coverage dependent beneficial electrocatalysis. R. Soc. Open Sci. 2017, 4, 171128. [CrossRef]

28. Kulesza, P.J.; Zak, J.K.; Rutkowska, I.A.; Dembinska, B.; Zoladek, S.; Miecznikowski, K.; Negro, E.; Di Noto, V.; Zelenay, P. Elucidation of role of graphene in catalytic designs for electroreduction of oxygen. Curr. Opin. Electrochem. 2018, 9, 257-264. [CrossRef] 
29. Tang, X.-Z.; Li, X.; Cao, Z.; Yang, J.; Wang, H.; Pu, X.; Yu, Z.-Z. Synthesis of graphene decorated with silver nanoparticles by simultaneous reduction of graphene oxide and silver ions with glucose. Carbon 2013, 59, 93-99. [CrossRef]

30. Kumar, S.; Selvaraj, C.; Scanlon, L.G.; Munichandraiah, N. Ag nanoparticles-anchored reduced graphene oxide catalyst for oxygen electrode reaction in aqueous electrolytes and also a non-aqueous electrolyte for Li-O2 cells. Phys. Chem. Chem. Phys. 2014, 16, 22830-22840. [CrossRef]

31. Lim, E.J.; Choi, S.M.; Seo, M.H.; Kim, Y.; Lee, S.; Kim, W.B. Highly dispersed Ag nanoparticles on nanosheets of reduced graphene oxide for oxygen reduction reaction in alkaline media. Electrochem. Commun. 2013, 28, 100-103. [CrossRef]

32. Soo, L.T.; Loh, K.S.; Mohamad, A.B.; Daud, W.R.W.; Wong, W.Y. Synthesis of silver/nitrogen-doped reduced graphene oxide through a one-step thermal solid-state reaction for oxygen reduction in an alkaline medium. J. Power Sources 2016, 324, 412-420. [CrossRef]

33. Wang, Y.; Qiao, Y.; Chen, Y.; Hu, T.; Zhang, L. One step pyrolysis synthesis of silver/nitrogen-doped carbon sheet for oxygen reduction in alkaline media. Int. J. Hydrogen Energy 2017, 42, 22903-22908. [CrossRef]

34. Guo, J.; Hsu, A.; Chu, D.; Chen, R. Improving Oxygen Reduction Reaction Activities on Carbon-Supported Ag Nanoparticles in Alkaline Solutions. J. Phys. Chem. C 2010, 114, 4324-4330. [CrossRef]

35. Muzyka, R.; Kwoka, M.; Smędowski, Ł.; Díez, N.; Gryglewicz, G. Oxidation of graphite by different modified Hummers methods. New Carbon Mater. 2017, 32, 15-20. [CrossRef]

36. Gautam, R.K.; Bhattacharjee, H.; Venkata Mohan, S.; Verma, A. Nitrogen doped graphene supported $\alpha-\mathrm{MnO}_{2}$ nanorods for efficient ORR in a microbial fuel cell. RSC Adv. 2016, 6, 110091-110101. [CrossRef]

37. Hsu, K.-C.; Chen, D.-H. Microwave-assisted green synthesis of Ag/reduced graphene oxide nanocomposite as a surface-enhanced Raman scattering substrate with high uniformity. Nanoscale Res. Lett. 2014, 9, 193. [CrossRef]

38. Goncalves, G.; Marques, P.A.A.P.; Granadeiro, C.M.; Nogueira, H.I.S.; Singh, M.K.; Grácio, J. Surface Modification of Graphene Nanosheets with Gold Nanoparticles: The Role of Oxygen Moieties at Graphene Surface on Gold Nucleation and Growth. Chem. Mater. 2009, 21, 4796-4802. [CrossRef]

39. Holzwarth, U.; Gibson, N. The Scherrer equation versus the 'Debye-Scherrer equation'. Nat. Nanotechnol. 2011, 6, 534. [CrossRef]

40. Zhang, J.; Guo, C.; Zhang, L.; Li, C.M. Direct growth of flower-like manganese oxide on reduced graphene oxide towards efficient oxygen reduction reaction. Chem. Commun. 2013, 49, 6334-6336. [CrossRef] [PubMed]

41. Kostowskyj, M.A.; Gilliam, R.J.; Kirk, D.W.; Thorpe, S.J. Silver nanowire catalysts for alkaline fuel cells. Int. J. Hydrogen Energy 2008, 33, 5773-5778. [CrossRef]

42. Hosseini, S.; Han, S.J.; Arponwichanop, A.; Yonezawa, T.; Kheawhom, S. Ethanol as an electrolyte additive for alkaline zinc-air flow batteries. Sci. Rep. 2018, 8, 11273. [CrossRef] [PubMed]

43. Hosseini, S.; Lao-atiman, W.; Han, S.J.; Arpornwichanop, A.; Yonezawa, T.; Kheawhom, S. Discharge Performance of Zinc-Air Flow Batteries Under the Effects of Sodium Dodecyl Sulfate and Pluronic F-127. Sci. Rep. 2018, 8, 14909. [CrossRef] [PubMed]

44. Yang, T.-H.; Venkatesan, S.; Lien, C.-H.; Chang, J.-L.; Zen, J.-M. Nafion/lead oxide-manganese oxide combined catalyst for use as a highly efficient alkaline air electrode in zinc-air battery. Electrochim. Acta 2011, 56, 6205-6210. [CrossRef]

45. Ma, H.; Wang, B. A bifunctional electrocatalyst $\alpha-\mathrm{MnO}_{2}-\mathrm{LaNiO}_{3} /$ carbon nanotube composite for rechargeable zinc-air batteries. RSC Adv. 2014, 4, 46084-46092. [CrossRef]

(C) 2020 by the authors. Licensee MDPI, Basel, Switzerland. This article is an open access article distributed under the terms and conditions of the Creative Commons Attribution (CC BY) license (http://creativecommons.org/licenses/by/4.0/). 